\title{
The Little Ice Age glacier maximum in Iceland and the North Atlantic Oscillation: Evidence from Lambatungnajökull, southeast Iceland
}

\author{
TOM BRADWELL, ANDREW J. DUGMORE AND DAVID E. SUGDEN
}

Bradwell, T., Dugmore., A.J. \& Sugden, D.E.: The Little Ice Age glacier maximum in Iceland and the North Atlantic Oscillation: Evidence from Lambatungnajökull, southeast Iceland.

This paper examines the link between Late Holocene fluctuations of Lambatungnajökull, an outlet glacier of the Vatnajökull ice cap in Iceland, and variations in climate.

Geomorphological evidence is used to reconstruct the pattern of glacier fluctuations; whilst lichenometry and tephrostratigraphy are used to date glacial landforms deposited over the last $\sim 400$ years. Moraines dated using two different lichenometric techniques indicate that the most extensive period of glacier expansion occurred shortly before $c$. AD 1795, probably during the 1780s. Recession over the last 200 years was punctuated by re-advances in the 1810s, 1850s, 1870s, 1890s and c. 1920, 1930 and 1965. Lambatungnajökull receded more rapidly in the 1930s and 1940s, than at any other time during the last 200 years. The rate and style of glacier retreat since 1930 compare well with other similar-sized, non-surging, glaciers in southeast Iceland, suggesting that the terminus fluctuations are climatically driven. Furthermore, the pattern of glacier fluctuations over the $20^{\text {th }}$ century broadly reflects the temperature oscillations recorded at nearby meteorological stations. Much of the climatic variation experienced in southern Iceland, and the glacier fluctuations that result, can be explained by secular changes in the North Atlantic Oscillation (NAO). Advances of Lambatungnajökull generally occur during prolonged periods of negative NAO index. The main implication of this work relates to the exact timing of the Little Ice Age in the Northeast Atlantic. Mounting evidence now suggests that the period between AD 1750-1800, rather than the late $19^{\text {th }}$ century, represented the culmination of the Little Ice Age in Iceland.

Tom Bradwell1' (e-mail: tbrad@bgs.ac.uk), Andrew J. Dugmore, D.E. Sugden, School of GeoSciences, University of Edinburgh, EH8 9XP, UK. ${ }^{1}$ Present address: British Geological Survey, West Mains Road, Edinburgh, EH9 3LA, UK 
Glaciers and small ice caps in temperate environments are sensitive indicators of climatic change. Iceland is an important location for the study of North Atlantic climate change owing to its proximity to both atmospheric and oceanic polar fronts. Geomorphological evidence of glacier fluctuations in Iceland during the Late Holocene is abundant. Furthermore, Iceland has a unique documentary record of icefront positions between the time of settlement, around AD 870, to the early $20^{\text {th }}$ century (Magnússon 1610; Palsson 1795; Thórarinsson 1943). Many of Iceland’s larger outlet glaciers have been systematically monitored since 1930 (Eythorsson 1935; Sigurðsson 1998). Consequently, a general description of glacier conditions exists for the last 1000 years (Thórarinsson 1943), in addition to a detailed knowledge of ice-front fluctuations for the last 70 years (Sigurðsson 1998).

Previous studies of glacier forelands in southeast Iceland conclude that glaciers reached their Late Holocene maxima during the late $19^{\text {th }}$ century (Ives 1956; Jaksch 1970, 1975; Gordon \& Sharp 1983; Sharp 1984; Snorrason 1984; Sharp \& Dugmore 1985; Thompson \& Jones 1986; Thompson 1988; Gudmundsson 1997, 1998; Evans et al. 1999; Dabski 2002). With only one or two exceptions, the outermost historical moraines around the Vatnajökull ice cap are attributed to readvances between AD 1850-1900. Consequently, the idea of a broadly synchronous late- $19^{\text {th }}$ century glacier maximum in Iceland has been widely accepted (Björnsson 1979; Gudmundsson 1997; Evans et al. 1999).

Recently this concept has been challenged. Kirkbride \& Dugmore (2001) found moraines in southern Iceland relating to the Eyjafjallajökull ice cap dating from the mid $18^{\text {th }}$ century. Tephrostratigraphic evidence brackets the advances of Gigjökull and Steinholtsjökull to the period AD 1727-1755. Furthermore, moraines at Tungnakvislajökull, an outlet of the Myrdalsjökull ice cap, have been attributed to an advance in the early part of the $19^{\text {th }}$ century, based on lichenometric and tephrastratigraphic evidence (Casely \& Dugmore 2004). Entujökull, draining the northern flank of Mýrdalsjökull was also probably more extensive in the late $18^{\text {th }}$ and early $19^{\text {th }}$ centuries than at any time since (Smith, 2004). Adjacent to the Öræfajökull ice cap in southeast Iceland, Gudmundsson (1998) found tephrochronological evidence of historical glacier fluctuations pre-dating the period AD 1700-1900. 
Svínafellsjökull, Virkisjökull and Kvíárjökull possess small moraine fragments dating from around the $13^{\text {th }}$ century, implying that all three glaciers were more extensive than in later centuries. The moraine in front of Svínafellsjökull is a composite feature and probably also marks the extent of a pre-historic advance (c. $2000 \mathrm{yrs} \mathrm{BP),} \mathrm{as} \mathrm{well}$ as a more recent advance in the early $18^{\text {th }}$ century (1727-1755) (Gudmundsson 1998). Breiðamerkurjökull, a surging outlet glacier, is known to have fluctuated around its maximum position throughout the $19^{\text {th }}$ century (Evans \& Twigg 2002). Bradwell (2004a) also found evidence of late $18^{\text {th }}$ and early $19^{\text {th }}$ century advances at two glaciers draining the southern flanks of Öræfajökull. The outermost moraine fragment at Fjallsjökull, dated using the gradient of the lichen size-frequency distribution, probably formed during the 1780s (Bradwell 2004a).

The question of glacier synchrony in Iceland is complicated somewhat by the presence of subglacial volcanic centres. The ice caps of Öræfajökull, Eyjafjallajökull and Mýrdalsjökull are all situated on active volcanoes. Öræfajökull has erupted only twice in the last 1000 years - in 1362 and 1727 - leading some to conclude that there may be a connection between periods of volcanic activity and glacier advances (Gudmundsson 1998; Larsen 2000). Regardless of any apparent connection, there is still some doubt as to whether the marginal fluctuations of ice caps draining active volcanoes are truly representative of climatic change (Thórarinsson 1943; Sturm et al., 1991). Hence, the findings of Gudmundsson (1998), Kirkbride \& Dugmore (2001), Bradwell (2004a), and Casely \& Dugmore (2004) may not be applicable across Iceland as a whole. 


\section{Rationale and study area}

In order to examine whether ice-front fluctuations in Iceland are representative of climatic conditions it is important to select a glacier that fulfils several criteria, namely:

1. The glacier is located outside the Neo-volcanic zone and sufficiently far away from high-temperature areas to reduce the effects of geothermal heating on glacier flow.

2. The glacier is not prone to jökulhlaup floods, thus making moraine preservation more likely.

3. The glacier has a high mass turnover, and is thus sensitive to changes in climate.

4. The glacier is non-surging and therefore more likely to reflect purely climatic change.

5. The glacier possesses a topographically constrained accumulation area, making problems relating to ice-divide migration less likely.

6. The glacier terminates in a valley, rather than as a broad unconfined lobe, making small changes in mass balance more likely to be expressed in changes in the location of the terminus. The presence of a confined meltwater system would also aid preservation of the geomorphic record.

7. The glacier has a good moraine record.

Only three areas of Iceland fulfil the first three criteria: eastern Vatnajökull, Drangajökull in the northwest, and Tröllaskagi in the north. However, the glaciers of the Tröllaskagi highlands are small corrie and plateau-fed glaciers located in the less maritime, sub-polar, climate of northern Iceland. Turnover rates here are not ideally suited for the study of high-resolution glacier fluctuations. Although located in a more maritime climate, the glaciers of Drangajökull are known to surge (Eythorsson 1935; Sigurðsson 1998) making them less appropriate for palaeo-climatic study. Only the glaciers draining the eastern flanks of Vatnajökull fulfil the first four criteria. Of eastern Vatnajökull’s 14 separate outlet glaciers (excluding the 9 of Öræfajökull draining an active volcano), only two fulfilled all seven criteria: - Lambatungnajökull and Öxarfellsjökull. Lambatungnajökull was chosen as the ideal focus of this study as it has a longer moraine record and is more accessible than Öxarfellsjökull. 


\section{Lambatungnajökull}

Lambatungnajökull is a little-studied glacier draining from the mountains of northeastern Vatnajökull (Fig. 1). It is a medium-sized warm-based outlet glacier that flows east. The overall surface long-profile of the glacier is relatively steep, falling almost $1000 \mathrm{~m}$ in only $10 \mathrm{~km}$ distance. The glacier has a high-elevation accumulation area (>1000 m a.s.l.) constrained by the underlying topography. The current ablation area, defined by the late-summer snowline, comprises $~ 35 \%$ of the glacier's total area. Calculations based on the 1982 topographic survey place the equilibrium line at 980 m altitude (AAR = 0.6) (Fig. 2), in broad agreement with the ELA of 1000-1100 m derived by Ahlmann \& Thórarinsson (1937). Lambatungnajökull presently flows in a relatively narrow $\mathrm{U}$-shaped valley called Skyndidalur. The floor of this trough is $\sim 600 \mathrm{~m}$ below the surrounding mountains. Unlike many other glaciers in Iceland that terminate as broad lobes on level outwash plains, Lambatungnajökull and its associated meltwater system are confined by precipitous valley sides to the north and south.

\section{Present knowledge of glacier fluctuations at Lambatungnajokull}

Information regarding the former extent of Lambatungnajökull is limited. No detailed studies of the glaciers in this area have been published, possibly owing to their relative inaccessibility. However, there are fragmentary pieces of documentary, cartographic and photographic evidence relating to ice-marginal fluctuations of Lambatungnajökull over the last 400 years.

\section{Direct observations}

Although the ice-flow is presently confined to one valley, eye-witness accounts state that during previous periods of glacier growth the ice breached a col in the valley side and overflowed into the neighbouring valley of Hoffellsdalur. Sigurdur Thórarinsson visited Lambatungnajökull briefly in the summer of 1938. Thórarinsson (1943: p.6) states that the glacier was "just leaving the pass from Hoffellsdalur to Skyndidalur" during the autumn of 1938 and, with the aid of a map prepared in 1936 by the Danish Geodetic Survey, he partially sketched the glacier's extent in c. 1890 according to the farmer at Hoffell (Thórarinsson 1943: fig. 3) (Fig. 3). Thórarinsson believed this limit 
represented the "maximum extent in historical time” (i.e. the last 1000 years) (1943: p.6). Thoroddsen (1913-15: III, p.216) stated that the glacier in Hoffellsdalur reached the valley floor in 1894. Thórarinsson, probably quoting from Thoroddsen, also says that in 1894 the main lobe of the glacier "ran right across Skyndidalur" and thus had retreated 700-800 m by 1936 (Fig. 3).

More recently, the retreat of the southern margin of Lambatungnajökull was monitored by the farmer at Hoffell between 1935 and 1945 (Sigurðsson 1998). The glacier is listed in the Icelandic Glaciological database as Hoffellsdalsjökull.

\section{Documentary / anecdotal evidence}

Árni Magnússon’s Chorographica written in c. AD 1705 tells of a path that was only accessible when the margin of Lambatungnajökull did not occupy the col in Hoffellsdalur. Soon after c. 1650 the path was impassable “owing to glaciers”. In 1936 this path became accessible once again, allowing farmers access into the valley of Fossdalur and the interior of Vatnajökull. Thórarinsson states that Lambatungnajökull must therefore have been smaller in c.AD 1640 than in the early 1930s (Thórarinsson 1943: p.7).

A further written account by Sigurður Stefánsson of Holt farm in 1746 (quoted in Thórarinsson, 1943: p.6) states that the river flowing in Hoffellsdalur was a ‘bergvatn’ not a glacial meltwater river ('jökulsá’). This led Thórarinsson (1943: p.6) to propose that Lambatungnajökull was less extensive in 1746 than in 1936. However the validity of this statement could be questioned, since even during periods of more extensive glaciation the Hoffellsá river drains a predominantly non-glacial catchment. Any glacial meltwater streams emanating from Lambatungnajökull may have been sufficiently diluted by the influx of water from non-glacial sources to appear as 'bergvatn' on arrival at Holt, 15 km downstream. 


\section{Cartographic evidence}

Maps of Iceland date back to the early $15^{\text {th }}$ century. However, the scale and accuracy of these earliest maps make them of little use for quantitative studies of glacier fluctuations. The first detailed trigonometrical survey of Iceland was carried out by the Danish General Staff between 1902 and 1904. Unfortunately, Lambatungnajökull and much of eastern Vatnajökull remained unsurveyed until 1936. The first accurate topographic maps of this area were published in 1938 at 1:100,000 scale (sheets 106, 107). The National Land Survey of Iceland produced revised sheets in 1962, 1983 and 1998.

Lambatungnajökull also appears on the 1:50,000 US Army Series (C762) maps compiled from aerial photographs taken in 1945-46 (sheets 55 \& 56). These maps were revised in 1988-90 using high-resolution satellite images. Cartographic evidence shows that c. $1000 \mathrm{~m}$ of ice-front recession has occurred at Lambatungnajökull since 1936.

\section{Photographic evidence}

Aerial photographs of Iceland, taken at regular intervals since 1945, provide a valuable source of information regarding ice-front fluctuations during the last 60 years. Aerial photography of Vatnajökull was carried out by the US Army in 194546, and by the National Land Survey of Iceland in 1957, 1960-61, 1967, 1982, 198990 and 1998. Five aerial sorties capture the terminus of Lambatungnajökull between 1946 and 2000 (3 of these are shown in Fig. 4).

The former extent of Lambatungnajökull at various times over the last four centuries has been deduced from historical sources, aerial photographs, published maps and observations (Fig. 5). Since 1936 the position of the ice margin can be quite well constrained. However, prior to the mid- $20^{\text {th }}$ century, knowledge of Lambatungnajökull is limited. Documentary historical sources have been used to infer the approximate position of the glacier front during previous centuries (eg. Thórarinsson 1943). Yet certain assumptions, particularly regarding the glacier extent in the $17^{\text {th }}$ and $18^{\text {th }}$ centuries, should be treated with caution. 


\section{Methods}

This study uses geomorphological mapping combined with lichenometry and tephrochronology to reconstruct the glacial history of Lambatungnajokull in detail. All landforms relating to glaciation in the valleys of Skyndidalur and Hoffellsdalur were mapped. Particular emphasis was placed on features relating to ice-marginal positions; namely end and lateral moraines, ice-contact ramps and fans, abandoned overflow channels, ice-dammed lake shorelines and erosional trimlines.

Lichenometric investigations were carried out on all moraines.

During 1998 and 1999 approximately 300 yellow-green Subgenus Rhizocarpon lichens were measured on each of 45 moraine fragments relating to the former margin of Lambatungnajökull. All lichen measurements were of the longest axis and all surveys were conducted on ice-proximal slopes. Care was taken to restrict measurements to thalli of Rhizocarpon section Rhizocarpon and exclude lichens of section Alpicola, known to grow at different rates (Innes 1982, 1983). Owing to the difficulties surrounding field identification to the species level, thalli were only identified to the section level as recommended by Innes (1982, 1985) using the criteria of Poelt (1988). Consequently, to avoid misidentification, thalli less than 5 $\mathrm{mm}$ in diameter were omitted from the survey. Rhizocarpon section Rhizocarpon (formerly known as the Geographicum group (Runemark 1956)) includes the species Rhizocarpon geographicum (L.) DC. (Cernohorský 1977). Measurements were made to the nearest millimetre and were conducted within a fixed area (normally $30-50 \mathrm{~m}^{2}$ ). Elongate and misshapen thalli were included in the survey; coalescent thalli were not. Measurements were restricted to non-vesicular basaltic rocks, which are abundant in the study area. Over 15000 lichens were measured in total.

Size-frequency graphs were generated for each lichen survey. Linear regression analyses, using the least-squares regression method, were calculated for each size-frequency distribution. Surface exposure ages were derived using both the largest lichen (in a fixed area) and the gradient of the size-frequency ( $\left.\log _{10}\right)$ distribution, as recommended by Bradwell (2001, 2004a). This study also chose to use the lichen-dating curves presented in Bradwell (2001, 2004a) rather than curves derived by other workers. This was for 3 main reasons: firstly, most previous workers 
in southeast Iceland have carried out lichenometric surveys using the whole landform (e.g. Jaksch 1975; Thompson \& Jones 1986; Evans et al. 1999). These studies cannot be directly compared with those using a fixed area, as the size of the largest lichen recorded depends on the size of the area searched (Innes, 1984). Secondly, the curves presented by Bradwell (2001, 2004a) were constructed using only clearly identifiable surfaces of undisputed age and similar size, unlike some previous studies (e.g. Jaksch 1975; Evans et al. 1999). Finally, most previous studies in Iceland have used the average of the five largest lichens as the best measure of surface age. However, recent lichenometric research has shown that a description of the lichen size-frequency distribution presents a statistically robust and more powerful technique than using the single largest or several largest lichen thalli (Caseldine 1991; Bull \& Brandon, 1998; Bradwell 2004a, McKinzey et al. 2004; Lowell et al. 2005).

Pits were dug where soils had accumulated between moraines. Tephra layers were identified based on visible properties (eg. colour, texture, stratigraphy) and, where possible, stratigraphically correlated. Soil accumulation rates were used to constrain minimum landform ages in some circumstances.

\section{Results}

There are numerous landforms in Skyndidalur, Hoffelsdalur and Fossdalur relating to the former extent of Lambatungnajökull. Two different lichenometric approaches were used to date moraines in the study area - the size of the largest lichen in a fixed area and the gradient of the lichen size-frequency distribution. Exposure ages were derived using the curves constructed by Bradwell (2001, 2004a) (Figs. 6 \& 7). The results of the lichenometric surveys on the moraines are shown in Figures 9 and 10 and Tables 1, 2, \& 3.

The largest-lichen technique produces younger exposure ages than the gradient technique in all but a few cases, typically of 5 to $25 \%$. According to the gradient technique, the outermost moraine in Hoffellsdalur (H4) on which lichenometry was conducted yields a surface exposure date of AD $1796 \pm 12$. A similar age of $1805 \pm 12$ was derived for the outermost lateral moraine in Skyndidalur (S4). Later recessional moraines in both valleys were exposed around $1855 \pm 7,1880$ $\pm 6,1898 \pm 4$ and $1930 \pm 6$, according to the gradient technique. A closely spaced 
sequence of minor moraines in Skyndidalur are dated by lichenometry to between $1899 \pm 4$ and $\sim 1950$. Those formed since 1931 are sawtooth in plan and are more pronounced. The correspondence between the number of sawtooth moraines (13) and their timespan ( 14 years), indicate that they are probably annual moraines (Bradwell 2004b). Moraines relating to the small cirque glacier on Grasgiljatindur were exposed in $1864 \pm 7,1896 \pm 5$ and $1926 \pm 7$.

\section{Discussion}

\section{Lichenometric techniques}

Tephrostratigraphy can be used to verify the lichenometric approach used in southeast Iceland. In Hoffellsdalur, soil between moraines H8 and H9 contains two black tephra layers. Geochemical analyses from both layers show that the tephra is indistinguishable from Grimsvötn ash elsewhere in SE Iceland (McKinzey, pers comm., Grönvold \& Johannesson 1984). These tephra layers probably relate to the eruptions of Grimsvötn in AD 1922 and 1934, based on their field relationships and stratigraphic position (Fig. 11). The two tephra layers are separated by $35 \mathrm{~mm}$ of soil, equivalent to a soil accumulation rate of $2.9 \mathrm{~mm} / \mathrm{yr}$. This value is similar to those derived by Dugmore \& Buckland (1991) in Eyjafjallasveit. In Hoffellsdalur, 60 mm of soil accumulated between the abandonment of moraine H8 and the deposition of the AD 1922 tephra - equivalent to 20 years, assuming a constant soil accumulation rate. Lichen-dating evidence suggests that this surface was exposed in $1917 \pm 5$ or $1898 \pm 4$, using the largest-lichen and the gradient techniques respectively. The latter date is more consistent with the tephrastratigraphic evidence (i.e. exposure c. 1900), demonstrating that the largest-lichen within a fixed sample area may not be as an appropriate age descriptor as the gradient of the size-frequency distribution.

At Lambatungnajökull, the age of moraine H8 can be also corroborated using the limited amount of documentary evidence. Observations of the glacier margin's position at the end of the $19^{\text {th }}$ century (1890s) correspond with the position of moraines H6-H8 at the head of Hoffellsdalur (Thorodssen, 1913-1915; Thórarinsson, 1943) (Figure 3). The largest of these moraines (H8) was exposed in the late 1890s according to the gradient of the lichen size-frequency distribution. This further supports the validity of this dating technique 
Across the study as a whole, the gradient of the size-frequency distribution tends to represent the age of older surfaces more accurately than the largest lichen within the distribution. The standard errors associated with the age-size curve and age-gradient curve are comparable for the period 1800-1925. However, the precision of the age-gradient curve decreases significantly on surfaces less than 70 years old, due its exponential form. Aerial photographic evidence also suggests that the largest lichen is a more accurate and precise age indicator on surfaces deposited in the last 60-70 years (Bradwell 2004a, 2004b). Crucially, the chronology and ultimately the climatic interpretation of glacier fluctuations in the study area will differ depending on the technique used.

Based on all the available geomorphological and lichenometrical evidence, the glacier advances or stillstands that deposited the larger moraines at Lambatungnajökull occurred immediately prior to the following times (AD): Hoffellsdalur - 1796, 1816, 1857-64, 1870-80, 1892-99, 1926-30, 1965; Skyndidalur - 1805, 1817, 1853-58, 1870-80, 1899, 1923, 1931-34, 1965.

\section{Wider significance}

The record of Late Holocene glacier fluctuations reconstructed for Lambatungnajökull spans the last 250 years (Figs. 12 \& 13). The outermost moraines in Hoffelsdalur and Skyndidalur, on which meaningful lichenometric results were obtained, show that Lambatungnajökull reached its Little Ice Age maximum towards the end of the $18^{\text {th }}$ century, probably between $\sim 1780$ and 1795 . Since then, the glacier has undergone rapid retreat punctuated by periods of stillstand or readvance. The most notable of these resulted in moraine formation during the 1810s, 1850s, 1870s, 1890s and c. 1930.

The preservation of moraines relating to the former extent of Lambatungnajökull has been greatly aided by the fact that the glacier tongue no longer occupies Hoffellsdalur. This rather unusual setting may explain why the geomorphic record of glacier fluctuations is longer and more comprehensive at Lambatungnajökull than at most other glaciers in southeast Iceland. 
The $20^{\text {th }}$-century record of reconstructed glacier-front fluctuations at Lambatungnajökull compares well with those of other similar-sized, non-surging, outlets of southern Vatnajökull (Fig. 14). Measurements of ice-front recession at Skaftafellsjökull, Fjallsjökull, Skálafellsjökull and Fláajökull, taken from the Icelandic Glaciological Database (Sigurðsson 1998), are in good agreement with those reconstructed for Lambatungnajökull. Both the magnitude of glacier recession and the timing of various stillstands and advance events correspond quite closely between all five glaciers. Overall, Lambatungnajökull retreated c. $1100 \mathrm{~m}$ between 1930 and 2000; similar to the recession experienced at Skaftafellsjökull ( 1300 m), Skálafellsjökull ( 900 m), and Fláajökull ( 1400 m). The rate of recession at Lambatungnajökull was greatest between 1933 and 1950, and slowed in the 1960s. There has been little overall retreat since the 1980s. These trends are also reflected in the records of four comparable glaciers in southern Iceland (Fig. 14). All 5 glacier margins were stationary or re-advanced slightly between 1930-1934; 4 formed moraines in the period 1964-68; whilst 3 re-advanced or were stationary in the years 1979-82. Unfortunately, Skálafellsjökull and Fláajökull’s records are missing for this latter period (Sigurðsson 1998). The similarity between the $20^{\text {th }}$-century pattern of fluctuations of Lambatungnajökull and other glaciers in the region indicates that Lambatungnajökull is representative of glacier behaviour in southeast Iceland generally.

Thompson \& Jones (1986) studied the glacial deposits in front of Skaftafellsjökull and Svinafellsjökull in southeast Iceland and, using largest-lichen measurements, they reconstructed the record of fluctuations for the last 130 years. They found that, prior to monitoring began in 1933, glacier advances culminated around 1870, 1910, 1918-20 and 1930. Evans et al. (1999) studied several of Vatnajökull's glacier forelands and dated moraine fragments based on a linear lichen growth rate of $0.8 \mathrm{~mm} / \mathrm{a}$. They identified an early $20^{\text {th }}$-century readvance at Skalafellsjökull and Heinabergsjökull c. 1918-20. Dabski (2002) used a similar lichenometric methodology to extend the record of ice-front fluctuations at Fláajökull. He found a more complex pattern; with stillstands or advances in 1907, 1913, 192025 and 1930-32, as well as those observed in 1952-54 and 1980-82. Most recently, Bradwell (2004a) has used a statistically robust lichenometric technique to date the moraines in front of Fjallsjökull and Hólàrjökull. Bradwell’s reconstructed 
chronology confirmed the documentary evidence summarized by Thórarinsson (1943) pertaining to fluctuations of these glaciers. However, Bradwell (2004a) also found moraines relating to small advances immediately prior to 1904, 1907-10 and 1915-18. A more extensive, earlier, advance during the 1780s was identified at Fjallsjökull.

It is also interesting to note that the record of ice-front fluctuations reported in this study corresponds well with those reported from northern Iceland. Kugelmann (1991) constructed a lichenometric-dating curve using calibration surfaces within his study region. He dated moraines relating to small cirque and valley glaciers in the Tröllaskagi mountains. On the basis of lichenometric dating Kugelmann (1991) reconstructed glacier advances dating from $c$. AD 1810, 1850, the 1870s, 1890s and 1920s. Häberle (1991) dated moraines in the adjacent catchment within the Tröllaskagi mountains. He found evidence for glacier advances at Barkardalsjökull $c$. 1750, and during the 1830s and 1860s. Caseldine (1991) reviewed all the available evidence and drew similar conclusions, pointing to a Little Ice Age maximum in northern Iceland in the early $19^{\text {th }}$ century. Unfortunately, the oldest dates derived by Kugelmann and Häberle, and quoted by Caseldine (1991), lie outside the calibrated range of their lichen-dating curves and therefore remain open to question.

Further evidence for a climatic signal is found when the record of glacier fluctuations at Lambatungnajökull is compared with mean climatic conditions over the $20^{\text {th }}$ century. There is a particularly close correspondence between summer air temperature and the rate of ice-front recession of Lambatungnajökull during periods of overall retreat. Between 1930 and 1950 this relationship is striking (Bradwell, 2004b). The implication is that differences in ice-front retreat of Lambatungnajökull during the $20^{\text {th }}$ century can be largely attributed to variations in mean summer air temperature from year to year (Bradwell 2004b).

Advance events on a multi-annual timescale appear to be a more complex response to a combination of climatic variables. The glacier is most likely to advance as the result of a few years of below-average annual temperatures bringing a halt to recession. Winter precipitation also plays a significant role in affecting terminus fluctuations on a sub-decadal timescale. However, the signal is complicated by the lagged response of the glacier system and therefore cannot be clearly isolated. 


\section{North Atlantic Oscillation}

A large degree of North Atlantic inter-annual climatic variability can be explained by fluctuations in sea-level pressure that occur between $\sim 30$ and $70^{\circ} \mathrm{N}-$ known as the North Atlantic Oscillation (NAO) (Rogers, 1984). For example, in Bergen, Norway, $60 \%$ of the variations in wintertime precipitation can be accounted for by inter-annual fluctuations of the NAO (Hurrell, 1995). Similarly there is a high correlation between positive NAO phases and warmer, generally stormier, winters in the British Isles, western Scandinavia and Iceland (Jones et al., 1997).

When the record of ice-front fluctuations from Lambatungnajökull is compared with the wintertime NAO index since AD 1865 (Hurrell 1995), an interesting pattern emerges (Fig. 12). Glacier advances generally coincide with periods of persistent negative NAO (Dec-Mar) index. Four or more consecutive winters with negative NAO indices have occurred only four times since 1864 - in 1870-1873, 1915-1918, 1962-1965 and 1968-1971. Periods of glacier advance, or prolonged stillstand, at Lambatungnajökull occurred c. 1870, 1890, 1918-20, 1925-30 and 1965. Three of these advances correspond exactly with periods of four or more negative NAO years. Whilst the advance in 1890 corresponds with a period of generally negative NAO index (7 years in 11) (Fig. 12). Within the last 140 years, the 1960s was the decade with the most pronounced negative NAO index (8 years in 10) and was also the period when most of Iceland's glaciers started to re-advance (Johannesson \& Sigurðsson 1998). This pattern suggests that climatically sensitive glaciers in southeast Iceland are more likely to advance during periods of overall negative NAO (Dec-Mar) index. In sharp contrast, the years 1903-1915 and 19201954 included numerous, successive, positive NAO winters. These were also the periods of most rapid glacier recession in southern Iceland (Johannesson \& Sigurðsson 1998), including Lambatungnajokull.

However strong, the relationship is not a perfect one. The advance of Lambatungnajökull between 1925-30 is anomalous as it took place during a period of predominantly positive NAO index. It is also difficult to explain why the ice-fronts of many Vatnajökull outlet glaciers have showed a tendency to advance since the 1980s when there have been 16 positive NAO winters in 20 years (Fig. 12). This 
observation suggests that the relationship may not be a simple one. It is possible that a glaciological threshold has been breached breaking down the linkage between glacier behaviour in SE Iceland and the NAO. Nesje et al., (2000) found a strong link between the mass balance of maritime glaciers in Norway and phases of the NAO (Dec-Mar) index. Negative years result in a negative balance, whilst positive years when winter precipitation is high - result in an overall increase in glacier mass. New data from Lambatungnajökull would suggest that the opposite relationship is true in southeast Iceland. This may be related to the importance of seasonal temperature variations and ablation season duration, over winter precipitation, in controlling glacier mass balance and ultimately glacier length in southern Iceland (Ahlmann \& Thorarinsson 1937; Johannesson 1997; Mackintosh et al. 2002). More research is needed in order to ascertain the validity of this glacio-climatic association.

\section{Conclusions}

- Lambatungnajökull has responded dynamically to Late Holocene climatic change. Focusing on the last 400 years, the glacier grew in size between AD 1600 and 1700, as recorded in medieval documents. It probably continued to advance during much of the $18^{\text {th }}$ century. The glacier reached its greatest Little Ice Age extent in the late $18^{\text {th }}$ century, probably between AD 1780-1795. Since then Lambatungnajökull has undergone overall retreat punctuated by numerous advances and stillstands. The largest of these events formed moraines in the 1810s, 1850s, 1870s, 1890s and c.1920, 1930 and 1965. Ice-front recession was greatest during the 1930s and 1940s when retreat averaged 20 m per year. Difference rates of icefront retreat during the $20^{\text {th }}$ century can be largely attributed to variations in mean summer air temperature from year to year.

- Lambatungnajökull was considerably more extensive in the late $18^{\text {th }}$ century ( $A D \sim 1780-1800$ ) than in the second half of the $19^{\text {th }}$ century (AD 1850-1900). This sheds further light on the exact timing of the Little Ice Age glacier maximum in SE Iceland. Mounting evidence now suggests 
that the regional glacier maximum occurred between AD 1750-1800, rather than 100 years later.

- Broadly speaking, the pattern of glacier fluctuations at Lambatungnajökull over the last 200 years reflects the climatic changes that have occurred in southeast Iceland and the wider region. Much of the climatic variation experienced in Iceland over the last two centuries can be explained by secular changes in the North Atlantic Oscillation. On a decadal scale, new data from Lambatungnajökull suggests that there is a link between periods of successive negative winter NAO index and advances of the ice margin. A shift to more zonal atmospheric circulation, and a weaker Icelandic Low, may have been responsible for the climatic cooling and positive mass balance that caused the glacier advances of the $19^{\text {th }}$ and early $20^{\text {th }}$ centuries.

\section{Acknowledgements}

This work was funded by the Department of Geography, University of Edinburgh and the Royal Geographical Society (Dudley Stamp Memorial Trust). Thanks go to Jeremy Everest, Keiran Allen and Sara Strachan for their support in the field. Without Sara's help on the $27^{\text {th }}$ July 1998 this work might not have been completed.

\section{References:}

Ahlmann, H.W. \& Thórarinsson, S. 1937: Vatnajökull. Scientific results of the Swedish-Icelandic investigations. Geografiska Annaler 19, 146-231.

Björnsson, H. 1979: Glaciers in Iceland. Jökull 29, 74-80.

Bradwell, T. 2001: A new lichenometric dating curve for southeast Iceland. Geografiska Annaler 83A, 91-101.

Bradwell, T. 2004a: Lichenometric dating in southeast Iceland: the size-frequency approach. Geografiska Annaler 86A, 31-41.

Bradwell, T. 2004b: Annual moraines and summer temperatures at Lambatungnajökull, Iceland. Arctic, Antarctic and Alpine Research 36, 502-508. 
Bull, W.B. \& Brandon, M.T. 1998: Lichen dating of earthquake-generated rockfall events, Southern Alps, New Zealand. Geological Society of America Bulletin 110, 6084.

Caseldine, C.J. 1991: Lichenometric dating, lichen population studies and Holocene glacial history in Tröllaskagi, Northern Iceland. In Maizels, J.K. \& Caseldine, C.J. (eds.): Environmental Change in Iceland: Past and Present, 219-233. Kluwer, Dordrecht.

Casely, A.F. \& Dugmore, A.J. 2004: Climate change and 'anomalous' glacier fluctuations: the southwest outlets of Myrdalsjökull, Iceland. Boreas 33, 108-122.

Cernohorský, Z. 1977: Rhizocarpon Ram. em. Th. Fr. subgen. Rhizocarpon. In Poelt, J. \& Vezda, A. (eds.): Bestimmungsschlüssel Europäischer Flechten, Ergänzungsheft 1, 217-231. Vaduz, Cramer.

Dabski, M. 2002: Dating of the Flàajökull moraine ridges SE Iceland; comparison of the glaciological, cartographic and lichenometrical data. Jokull 51, 17-24.

Dugmore, A.J. \& Buckland, P. 1991: Tephrochronology and late Holocene soil erosion in south Iceland. In Maizels, J.K. \& Caseldine, C.J. (eds.): Environmental Change in Iceland: Past and Present, 147-159. Kluwer, Dordrecht.

Erikstad, L. \& Søllid, J.L. 1986: Neoglaciation in South Norway using lichenometric methods. Norsk Geografisk Tidsskrift 40, 85-103.

Evans, D.J.A. \& Twigg, D.R. 2002: The active temperate glacial landsystem: a model based on Breiðamerkurjökull and Fjallsjökull, Iceland. Quaternary Science Reviews 21, 2143-2177.

Evans, D.J.A., Archer, S. \& Wilson, D.J.H. 1999: A comparison of the lichenometric and Schmidt hammer dating techniques based on data from the proglacial areas of some Icelandic glaciers. Quaternary Science Reviews 18, 13-41.

Eythorsson, J. 1935: On the variation of glaciers in Iceland. Geografiska Annaler 12, 121-137.

Gordon, J.E. \& Sharp, M. 1983: Lichenometry in dating recent glacial landforms and deposits, southeast Iceland. Boreas 12, 191-200.

Grönvold, K. \& Johannesson, H. 1984: Eruption in Grimsvötn 1983: course of events and chemical studies of the tephra. Jökull 34, 1-11.

Gudmundsson, H. J. 1997: A review of the Holocene environmental history of Iceland. Quaternary Science Reviews 16, 81-92.

Gudmundsson, H.J. 1998: Holocene Glacier Fluctuations and Tephrochronology of the Örcefi district, Iceland. Ph.D. dissertation, University of Edinburgh. 
Häberle, T. 1991: Holocene glacial history of the Hörgárdalur area, Tröllaskagi, northern Iceland. In Maizels, J.K. \& Caseldine, C. (eds.): Environmental Change in Iceland: Past and Present,193-202. Kluwer, Dordrecht.

Hurrell, J.W. 1995: Decadal trends in the North Atlantic Oscillation regional temperatures and precipitation. Science 269, 676-679.

Innes, J.L. 1982: Lichenometric use of an aggregated Rhizocarpon 'species'. Boreas $11,53-57$.

Innes, J.L. 1983: Size-frequency distributions as a lichenometric technique: an assessment. Arctic and Alpine Research 15, 285-294.

Innes, J.L. 1984: The optimal sample size in lichenometric studies. Arctic and Alpine Research 16: 233-244.

Innes, J.L. 1985: Lichenometry. Progress in Physical Geography 9, 187-254.

Ives, J. 1956: Örcefi, Southeast Iceland: An essay in regional geomorphology. Ph.D. dissertation, McGill University.

Jaksch, K. 1970: Beobachtungen in den Gletschervorfeldern des Sólheima und Siðujökull im Sommer 1970. Jökull 20, 45-49.

Jaksch, K. 1975: Das Gletschervorfeld des Sólheimajökull. Jökull 20, 45-49.

Johannesson, T. 1997: The response of two Icelandic glaciers to climatic warming computed with degree-day mass balance model coupled to a dynamic glacier model. Journal of Glaciology 43, 321-327.

Johannesson, T. \& Sigurðsson, O. 1998: Interpretation of glacier variations in Iceland, 1930-1995. Jokull 45, 27-35.

Jones, P.D., Jonsson, T. \& Wheeler, D. 1997: Extension to the North Atlantic Oscillation using early instrumental pressure observations from Gibraltar and southwest Iceland. International Journal of Climatology 15, 1433-50.

Kirkbride, M.J. \& Dugmore, A.J. 2001: Can lichenometry be used to date the 'Little Ice Age' glacial maximum in Iceland? Climatic Change 48 (1), 151-167.

Kugelmann, O. 1991: Dating recent glacier advances in the SvarfaðardalurSkiðadalur area of northern Iceland by means of a new lichen curve. In Maizels, J.K. \& Caseldine, C. (eds.): Environmental Change in Iceland: Past and Present, 203-217. Kluwer, Dordrecht.

Larsen, G. 2000: Holocene Volcanism in Iceland and Tephrochronology as a Tool in Volcanology. Iceland 2000: Modern Processes and Past Environments. Abstract Volume, p120. University of Keele. 
Lowell, T.V., Schoenenberger, K., Deddens, J.A., Denton, G.H., Smith, C., Black, J. \& Hendy, C.H. 2005: Rhizocarpon calibration curve for the Aoraki/Mount Cook area of New Zealand. Journal of Quaternary Science 20, 313-325.

Mackintosh, A., Dugmore, A.J. \& Hubbard, A.L. 2002: Holocene climatic changes in Iceland: evidence from modelling glacier length fluctuations at Sólheimajökull Quaternary International 91: 39-52..

McKinzey, K.M., Orwin, J.O. \& Bradwell, T. 2004: Re-dating the moraines at Skálafellsjökull and Heinabergsjökull using different lichenometric methods: implications for the timing of the Icelandic Little Ice Age maximum. Geografiska Annaler 86A, 319-335.

Magnússon, Á. 1710. Chorographica Islandica, Universitets-biblioteket, Copenhagen.

Nesje, A., Lie, Ø. \& Dahl, S.O. 2000: Is the North Atlantic Oscillation reflected in Scandinavian glacier mass balance records? Journal of Quaternary Science 15, 587601.

Palsson, S. 1795: Försog til en Physisk Geographisk og Historisk Beskrivelse over de islanke Is-biaerge, 1792-1794. Naturhistorie Selskabet, Kobnhavn.

Poelt, J. 1988: Rhizocarpon Ram. em. Th. Fr. Subgen. Rhizocarpon in Europe. Arctic and Alpine Research, 20, 292-298.

Rogers, J.C. 1984: The association between the NAO and the SO in the Northern Hemisphere. Monthly Weather Review 112, 1999-2015.

Runemark, H. 1956: Studies in Rhizocarpon, I. Taxonomy of the yellow species in Europe. Opera Botanica 2, 1-152.

Sharp, M. 1984: Annual moraine ridges at Skálafellsjökull, south-east Iceland. Journal of Glaciology 30, 82-93.

Sharp, M. \& Dugmore, A.J. 1985: Holocene glacier fluctuations in eastern Iceland. Zeitschrift für Gletscherkunde und Glazialgeologie 21, 341-349.

Sigurðsson, O. 1998: Glacier variations in Iceland 1930-1995. Jökull 45, 3-26.

Smith, K.T. 2004: Holocene jökulhlaups, glacier fluctuations and palaeoenvironment, Mýrdalsjökull, South Iceland. Ph.D dissertation, University of Edinburgh.

Snorrason, S. 1984: Mýrarjöklar og vatnsdalur. Unpublished Cand. Real dissertation, University of Oslo.

Sturm, M., Hall, D., Benson, C., \& Field, O. 1991: Non-climatic control of glacier fluctuations in the Wrangell and Chugach Mountains, Alaska, USA. Journal of Glaciology, 37: 348-356. 
Thompson, A. 1988: Historical development of the proglacial landforms of Svinafellsjökull and Skaftafellsjökull, southeast Iceland. Jökull 38, 17-31.

Thompson, A. \& Jones, A. 1986: Rates and causes of proglacial river terrace formation in southeast Iceland: an application of lichenometric dating techniques. Boreas 15, 231-246.

Thórarinsson, S. 1943: Vatnajökull - Scientific results of the Swedish-Icelandic investigations 1936-1937-1938. Chapter IX: Oscillations of the Icelandic glaciers in the last 250 years. Geografiska Annaler 25, 1-54.

Thoroddsen, Th. 1913-1915: Ferdabók, I-IV. Kaupmannahöfn. 


\section{Captions for figures:}

Figure 1. Map of southeast Iceland showing the present-day distribution of glaciers and volcanoes. Little Ice Age moraines are also shown, most of which are believed to date from AD 1850-1890. Key to ice caps: A - Tungnafellsjökull; B - Öræfajökull; C - Jökultindur; D - Hofsjökull í Lóni; E - Drándarjökull; F - Snæfell. Key to outlet glaciers: 1 - Skeiðarárjökull; 2 - Skaftafellsjökull; 3 - Svínafellsjökull; 4 Virkisjökull; 5 - Hólárjökull; 6 - Kvíárjökull; 7 - Hrútárjökull; 8 - Fjallsjökull; 9 Breiðamerkurjökull; 10 - Skálafellsjökull; 11 - Heinabergsjökull; 12 - Fláajökull; 13 - Hoffellsjökull; 14 - Lambatungnajökull; 15 - Öxarfellsjökull; 16 Eyjabakkajökull.

Figure 2. Area / altitude distribution of Lambatungnajokull in 1982. Contours are at $100 \mathrm{~m}$ vertical intervals. Equilibrium-line altitude (calculated using $\mathrm{AAR}=0.6)$ shown as a dashed line.

Figure 3. Topographic map of the study area in AD 1998. [modified from US AMS map, surveyed in 1945]. Contours are at $100 \mathrm{~m}$ vertical intervals. The former extent of Lambatungnajökull in 1890 and 1936, taken from Thórarinsson (1943: p.6), is also shown.

Figure 4. The former extent of Lambatungnajökull: photographic evidence. Vertical aerial photographs taken in 1945, 1967 and 1982 reproduced at the same scale. North is to the right. Note the retreat of the southern margin (known as 'Hoffellsdalsjökull') into the main valley, Skyndidalur, between 1945 and 1967. (Photographs reproduced with kind permission of the National Land Survey of Iceland.)

Figure 5. The size of Lambatungnajökull since c. AD 1600 based on all the evidence prior to this research. Glacier size is expressed relative to its extent in AD 1936. The size of Lambatungnajökull in the 17th, 18th and 19th centuries is uncertain (dashed line). White points are based on documentary sources (Thórarinsson 1943). Black points are based on direct observations (Thorodssen, 1913-15; Thórarinsson, 1943; Sigurðsson, 1998) and, since 1945, aerial photographs.

Figure 6. Moraines relating to the former extent of Lambatungnajökull and the glacier on Grasgiljatindur. Contours are at $100 \mathrm{~m}$ vertical intervals. The glaciers are shown in their present-day positions (1998).

Figure 7. Largest-lichen vs surface age in southeast Iceland (single largest Rhizocarpon section Rhizocarpon lichen in a fixed area), from Bradwell (2001). 
Figure 8. Gradient of lichen size-frequency $\left(\log _{10}\right)$ distribution vs surface age in southeast Iceland, from Bradwell (2004a). (Rhizocarpon section Rhizocarpon lichens.)

Figure 9. Lichen size-frequency distributions on moraines in Hoffellsdalur, Skyndidalur and Fossdalur.

Figure 10. Surface exposure ages (AD) of moraines in the study area derived using two different lichenometric techniques. Dates derived using the largest lichen are in italic script; those derived using the gradient of the lichen size-frequency $\left(\log _{10}\right)$ distribution are in roman script.

Figure 11. Tephrostratigraphy recorded in soil profiles between moraines in Skyndidalur and Hoffellsdalur. Moraines are numbered S4, H4, etc. Tephra layers: G - Grimsvötn; Ö - Öræfajökull, ?A - possibly Askja. Estimated start of soil accumulation given below each profile. Note the contrast in soil depth between the moraines formed in the last $\sim 200$ years and further down valley.

Figure 12. Palaeo-geographical reconstructions of Lambatungnajökull at various times over the last 250 years.

Figure 13. Fluctuations of the terminus of Lambatungnajökull during for the past 400 years. Distances are expressed in kilometres from the 1945 terminus position in Skyndidalur. The position of the glacier margin prior to c. 1780 is uncertain and has been inferred from selected documentary evidence, cited by Thórarinsson (1943).

Figure 14. Terminus fluctuations of Lambatungnajökull compared with those of similar-sized valley glaciers in southeast Iceland, since AD 1930 (other data taken from Sigurðsson, 1998). The data are plotted relative to the terminus position in 1930, keeping with the convention of the Icelandic Glaciological Society.

Figure 15. Comparison of the North Atlantic Oscillation index with glacier fluctuations at Lambatungnajökull. The upper diagram shows the behaviour of Lambatungnajökull over the last 140 years (deduced in this study). Grey boxes represent the periods when the ice-front was advancing or stationary for a number of years. The lower graph shows the index of the NAO (Dec-Mar) from 1864 - 2000, as used by Hurrell (1995). The index is based on the difference in normalised sea-level pressure between Lisbon, Portugal and Stykkishólmur, Iceland. Sea-level pressure data have been normalised relative to the period 1864-1983. The data have been smoothed (heavy line) using a weighted, seven-point low-pass filter. Note how five of the six advances of Lambatungnajökull since 1865 coincide with periods of negative NAO index (both shaded). 
Table 1. Lichenometric data from moraines in Hoffellsdalur.

\begin{tabular}{|l|r|r|r|r|}
\hline Moraine & $\begin{array}{l}\text { Gradient of } \\
\text { size-frequency } \\
\text { distribution } \\
\text { (-ve) }\end{array}$ & $\begin{array}{l}\text { Date of surface } \\
\text { exposure (based } \\
\text { on age-gradient } \\
\text { curve) }\end{array}$ & $\begin{array}{l}\text { Largest lichen } \\
\text { diameter (mm) }\end{array}$ & $\begin{array}{l}\text { Date of surface } \\
\text { exposure (based } \\
\text { on age-size } \\
\text { curve) }\end{array}$ \\
\hline H4 & 0.0253 & $1796 \pm 12$ & 82 & $1790 \pm 10$ \\
\hline H5 & 0.0272 & $1816 \pm 11$ & 66 & $1855 \pm 7$ \\
\hline H5b & 0.0317 & $1835 \pm 9$ & 54 & $1891 \pm 5$ \\
\hline H6 & 0.0375 & $1862 \pm 7$ & 60 & $1875 \pm 6$ \\
\hline H6 & 0.0370 & $1857 \pm 7$ & 49 & $1866 \pm 7$ \\
\hline H6b & 0.0361 & $1855 \pm 7$ & 51 & $1902 \pm 5$ \\
\hline H7 & 0.0408 & $1870 \pm 6$ & 54 & $1890 \pm 5$ \\
\hline H7b & 0.0461 & $1880 \pm 6$ & 55 & $1888 \pm 6$ \\
\hline H7b & 0.0453 & $1882 \pm 6$ & 42 & $1917 \pm 5$ \\
\hline H8 & 0.0540 & $1898 \pm 4$ & 50 & $1901 \pm 5$ \\
\hline H8b & 0.0500 & $1892 \pm 5$ & 46 & $1910 \pm 4$ \\
\hline H8b & 0.0549 & $1899 \pm 4$ & 39 & $1922 \pm 4$ \\
\hline H8c & 0.0642 & $1912 \pm 4$ & 30 & $1934 \pm 4$ \\
\hline H9 & 0.0814 & $1928 \pm 6$ & 36 & $1926 \pm 4$ \\
\hline H10 & 0.0776 & $1926 \pm 5$ & 35 & $1927 \pm 4$ \\
\hline H11 & 0.0829 & $1930+6$ & 26 & $1941 \pm 3$ \\
\hline H12 & 0.1171 & $1948 \pm 13$ & 21 & $1948 \pm 3$ \\
\hline H13 & 0.1527 & $>1960$ & & \\
\hline
\end{tabular}


Table 2. Lichenometric data from moraines in Skyndidalur.

\begin{tabular}{|l|r|r|r|r|}
\hline Moraine & $\begin{array}{l}\text { Gradient of } \\
\text { size-frequency } \\
\text { distribution } \\
\text { (-ve) }\end{array}$ & $\begin{array}{l}\text { Date of surface } \\
\text { exposure (based } \\
\text { on age-gradient } \\
\text { curve) }\end{array}$ & $\begin{array}{l}\text { Largest lichen } \\
\text { diameter (mm) }\end{array}$ & $\begin{array}{l}\text { Date of surface } \\
\text { exposure (based } \\
\text { on age-size } \\
\text { curve) }\end{array}$ \\
\hline S4 & 0.0315 & $1835 \pm 10$ & 72 & $1832 \pm 8$ \\
\hline S4* & 0.0263 & $1805 \pm 12$ & 68 & $1848 \pm 7$ \\
\hline S4b & 0.0286 & $1817 \pm 11$ & 74 & $1825 \pm 9$ \\
\hline S5 & 0.0373 & $1858 \pm 7$ & 60 & $1875 \pm 6$ \\
\hline S5b & 0.0358 & $1853 \pm 7$ & 65 & $1858 \pm 7$ \\
\hline S5e & 0.0370 & $1857 \pm 7$ & 60 & $1875 \pm 6$ \\
\hline SS & 0.0363 & $1854 \pm 7$ & 53 & $1893 \pm 5$ \\
\hline SN & 0.0362 & $1854 \pm 7$ & 62 & $1869 \pm 6$ \\
\hline S6 & 0.0398 & $1866 \pm 6$ & 56 & $1885 \pm 6$ \\
\hline S6b* & 0.0453 & $1880 \pm 6$ & 50 & $1901 \pm 5$ \\
\hline S6b** & 0.0407 & $1870 \pm 6$ & 36 & $1885 \pm 6$ \\
\hline S6b & 0.0700 & $1919 \pm 5$ & 38 & $1923 \pm 4$ \\
\hline S7 & 0.0549 & $1899 \pm 4$ & 38 & $1912 \pm 4$ \\
\hline S8 & 0.0730 & $1923 \pm 5$ & 39 & $1924 \pm 4$ \\
\hline S8** & 0.0654 & $1915 \pm 5$ & 32 & $1931 \pm 3$ \\
\hline S9 & 0.0833 & $1931 \pm 6$ & 32 & $1931 \pm 3$ \\
\hline S9c & 0.0793 & $1927 \pm 6$ & 33 & $1930 \pm 3$ \\
\hline S9d & 0.0834 & $1931 \pm 6$ & 32 & $1931 \pm 3$ \\
\hline S9e & 0.0858 & $1932 \pm 6$ & 30 & $1934 \pm 3$ \\
\hline S9f & 0.0999 & $1940 \pm 10$ & 10 & $1965 \pm 2$ \\
\hline S10 & 0.2832 & $>1960$ & & \\
\hline
\end{tabular}

\footnotetext{
* - lichens sampled from crest of moraine

** - lichens sampled from ice-distal flank of moraine

un - the ice-proximal flank of moraine S6b is oversteepened and unstable, subsequently the lichenometric data do not accurately represent the timing of surface exposure.
} 
Table 3. Lichenometric data from moraines in Fossdalur.

\begin{tabular}{|l|l|l|r|r|}
\hline Moraine & $\begin{array}{l}\text { Gradient of } \\
\text { size-frequency } \\
\text { distribution } \\
\text { (-ve) }\end{array}$ & $\begin{array}{l}\text { Date of surface } \\
\text { exposure (based } \\
\text { on age-gradient } \\
\text { curve) }\end{array}$ & $\begin{array}{l}\text { Largest lichen } \\
\text { diameter (mm) }\end{array}$ & $\begin{array}{l}\text { Date of surface } \\
\text { exposure (based } \\
\text { on age-size } \\
\text { curve) }\end{array}$ \\
\hline \multicolumn{5}{|l|}{ Moraines relating to Lambatungnajökull } \\
\hline L2 & 0.0509 & $1892 \pm 5$ & 44 & $1914 \pm 4$ \\
\hline L3 & 0.0862 & $1932 \pm 6$ & 36 & $1926 \pm 4$ \\
\hline Moraines relating to glacier on Grasgiljatindur \\
\hline G1 & 0.0383 & $1864 \pm 7$ & 59 & $1878 \pm 6$ \\
\hline G3 & 0.0528 & $1896 \pm 5$ & 43 & $1915 \pm 4$ \\
\hline G4 & 0.0788 & $1927 \pm 6$ & 33 & $1930 \pm 3$ \\
\hline G5 & 0.1261 & $1951 \pm 16$ & 24 & $1943 \pm 3$ \\
\hline
\end{tabular}




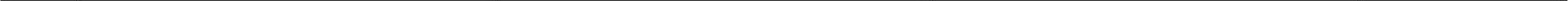




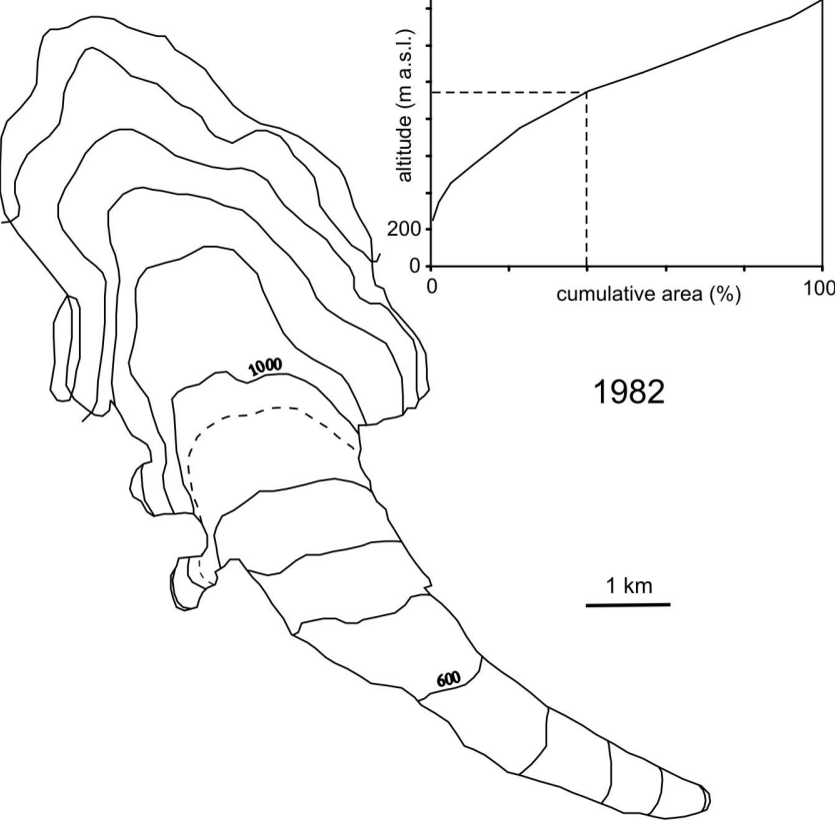




\section{Lambatungnatindur}
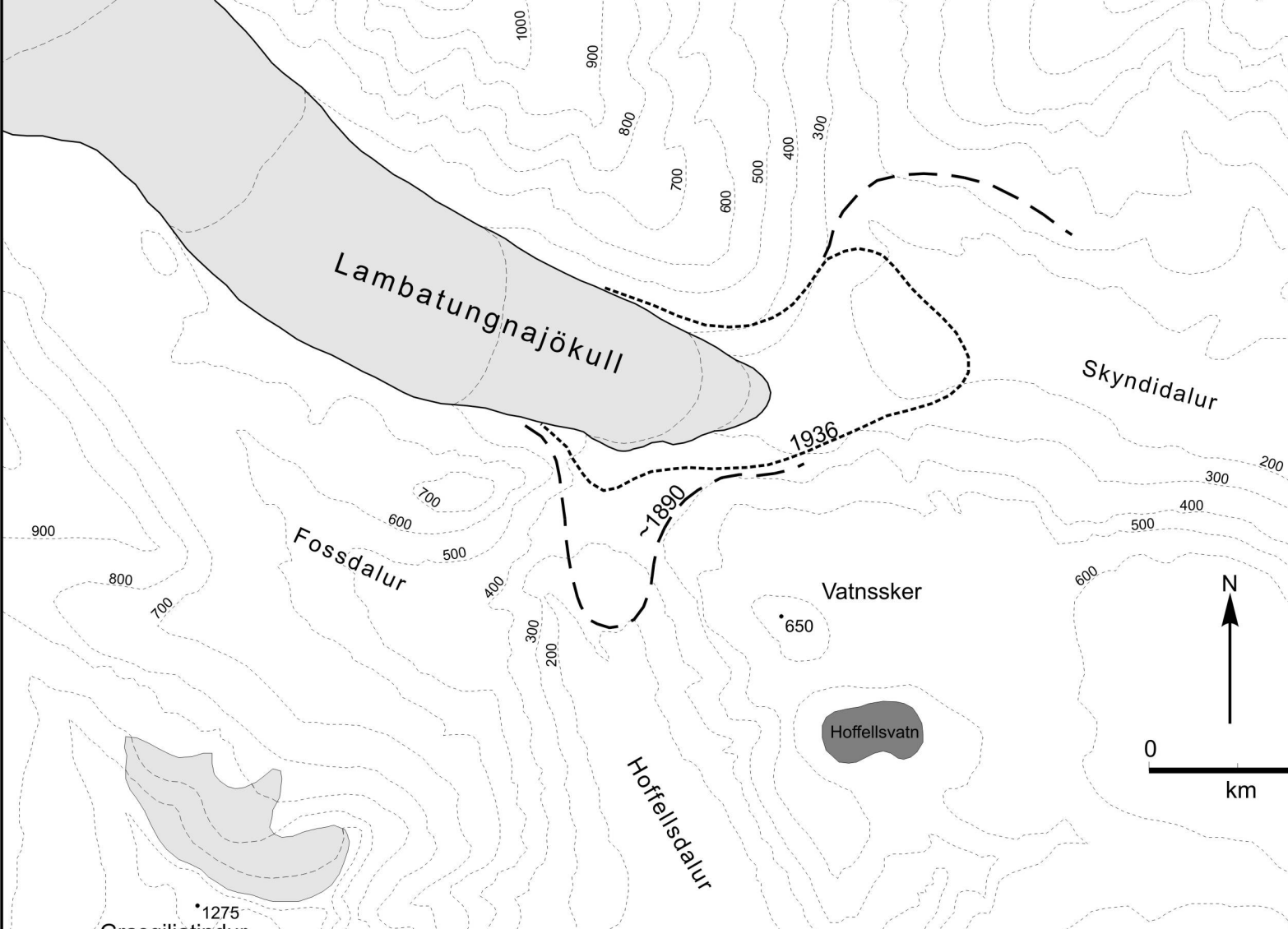

Hoffellsvatn

Grasgiljatindur 


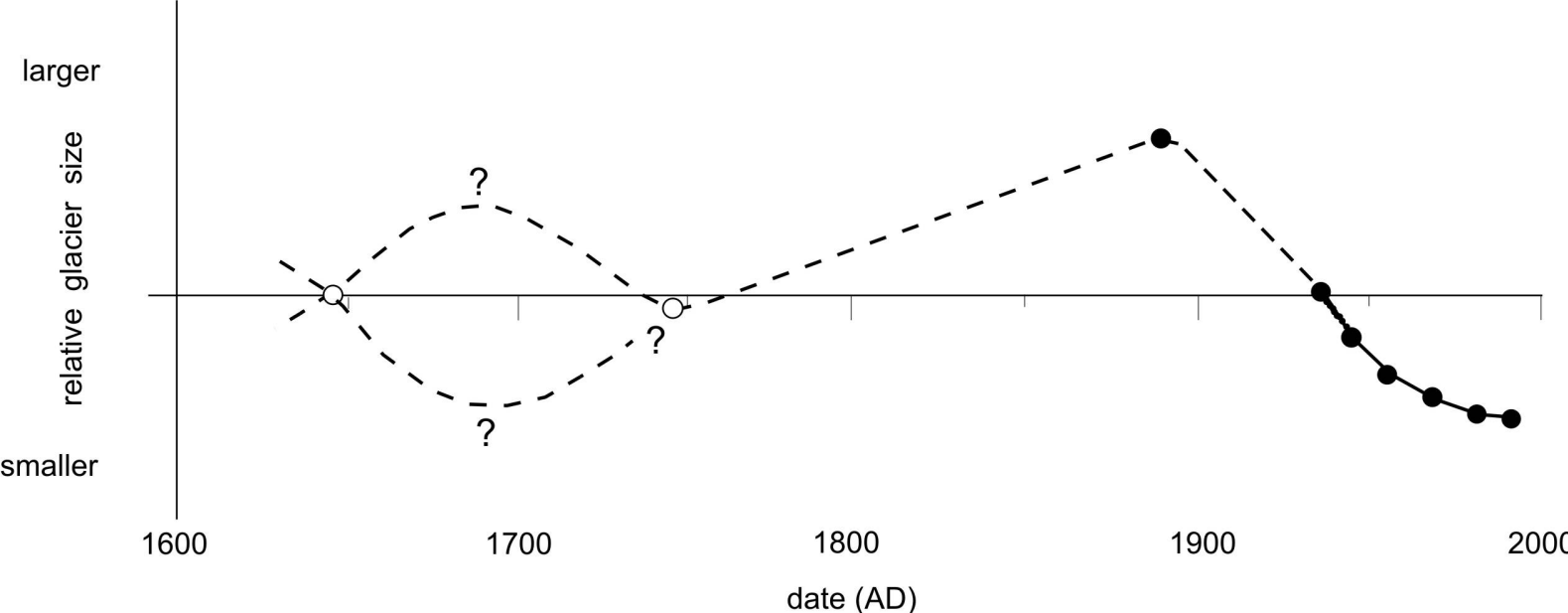




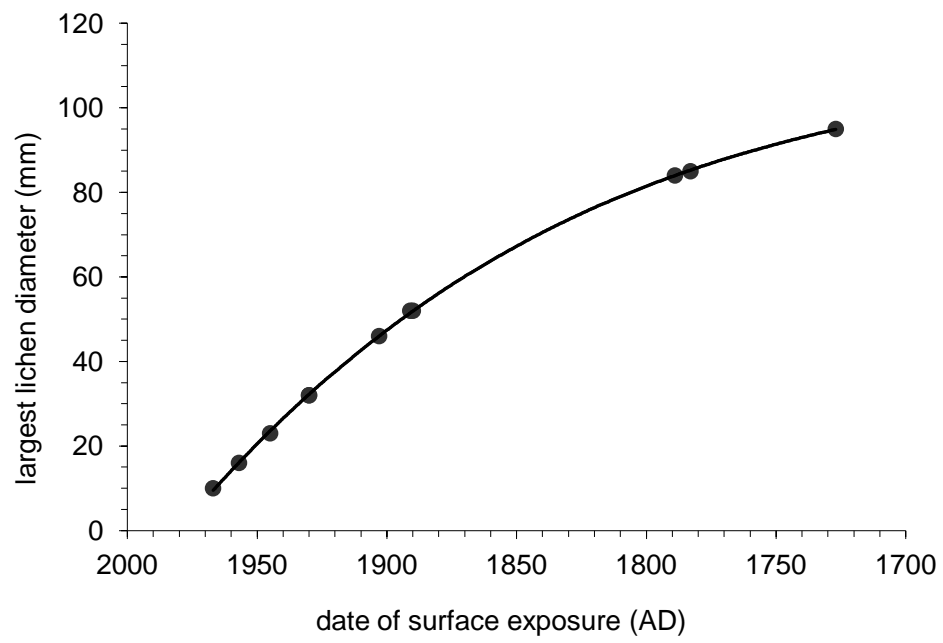




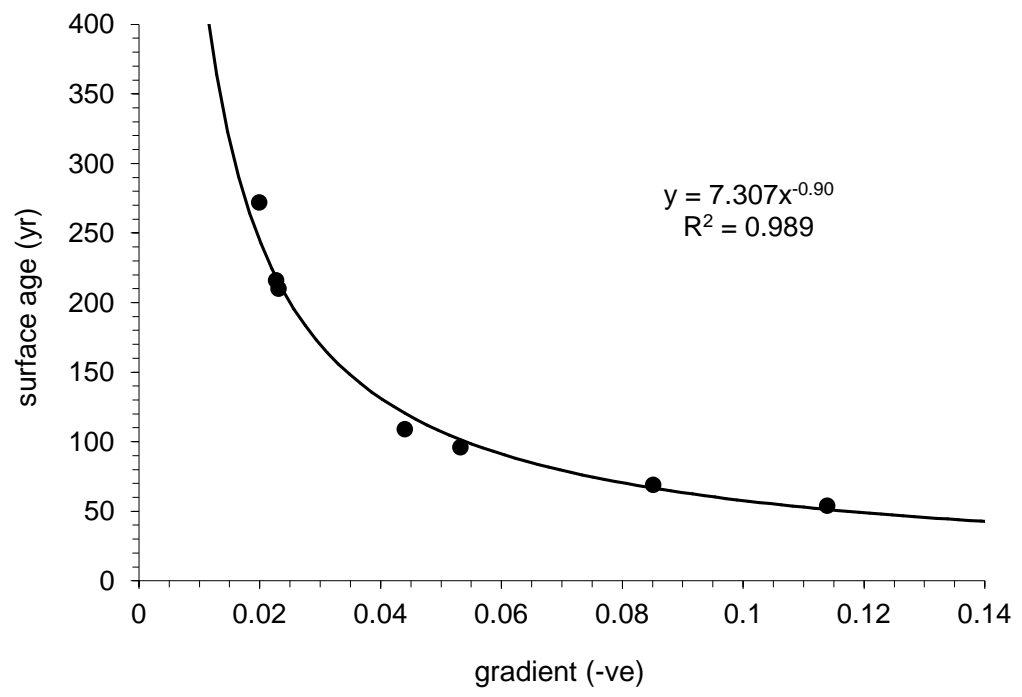


L2

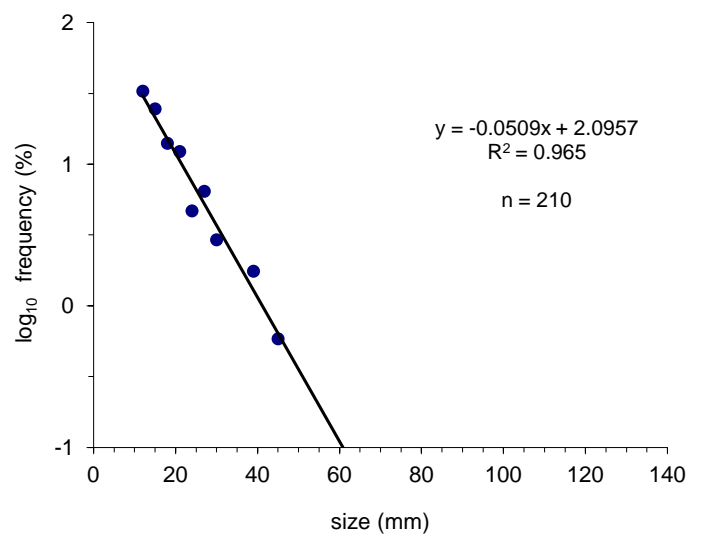

G1

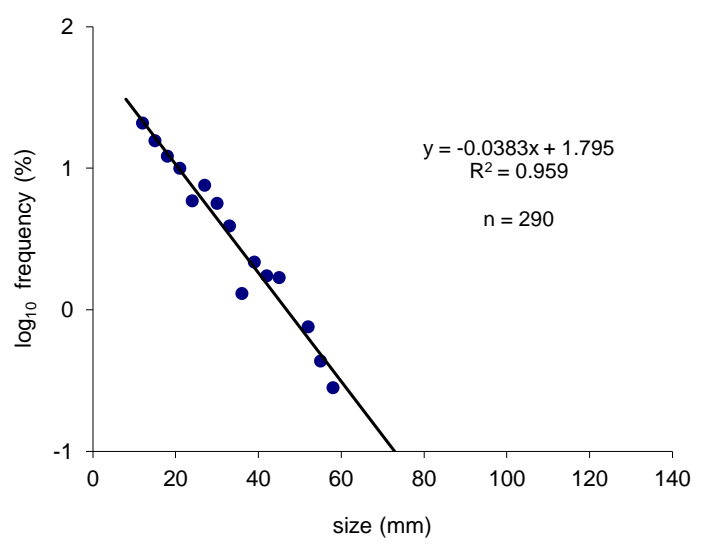

L3

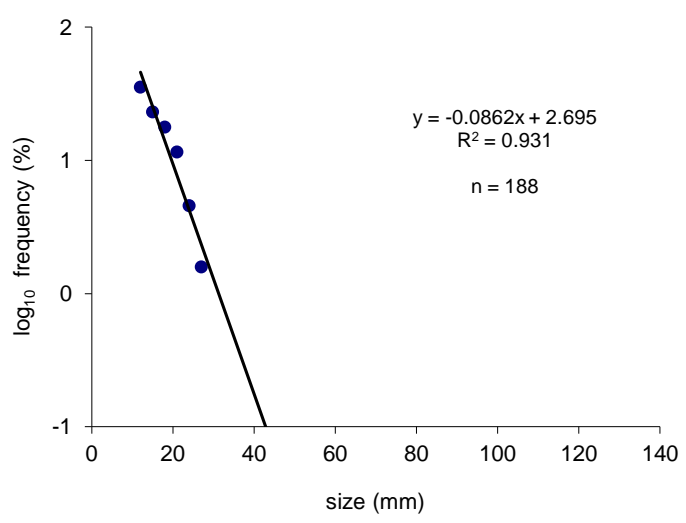

G3

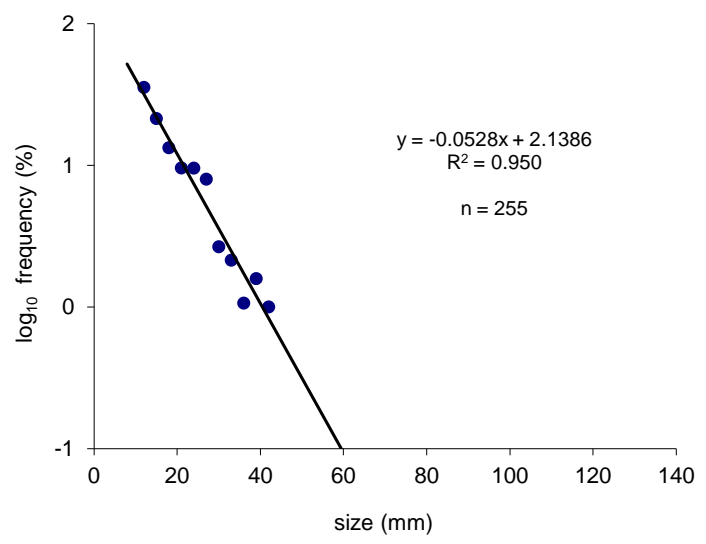

hor+A1 
H4

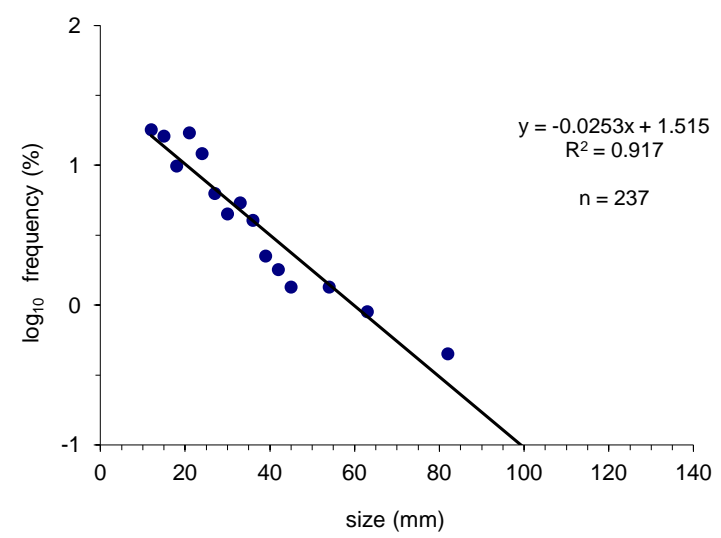

H6

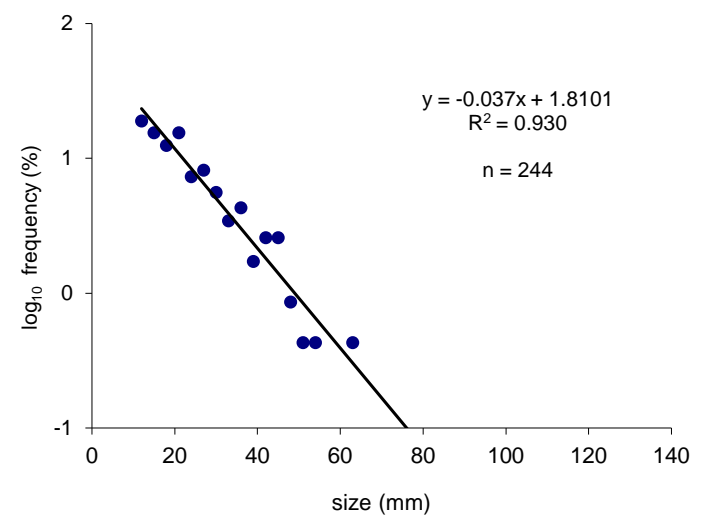

H7

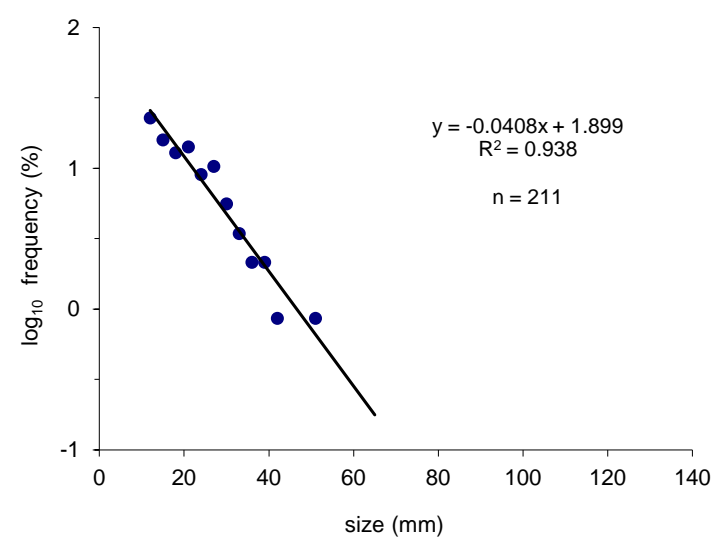

H5b

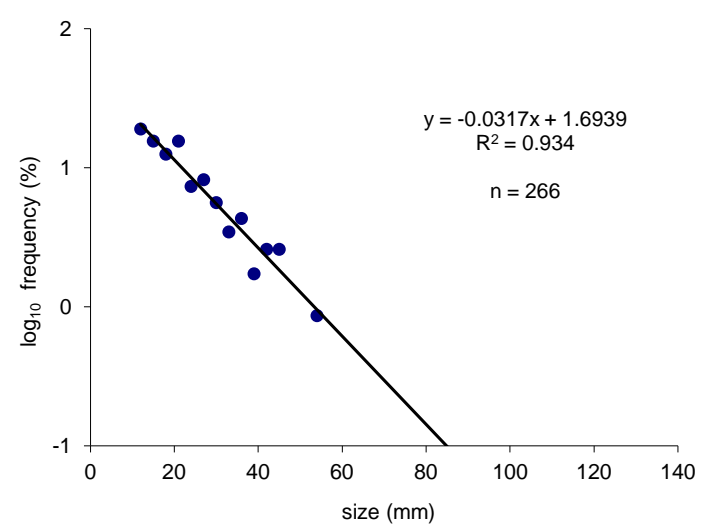

H6b

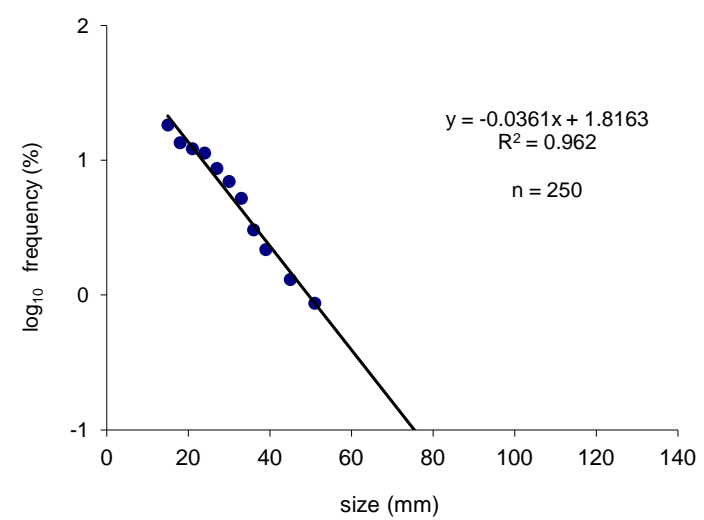

H8

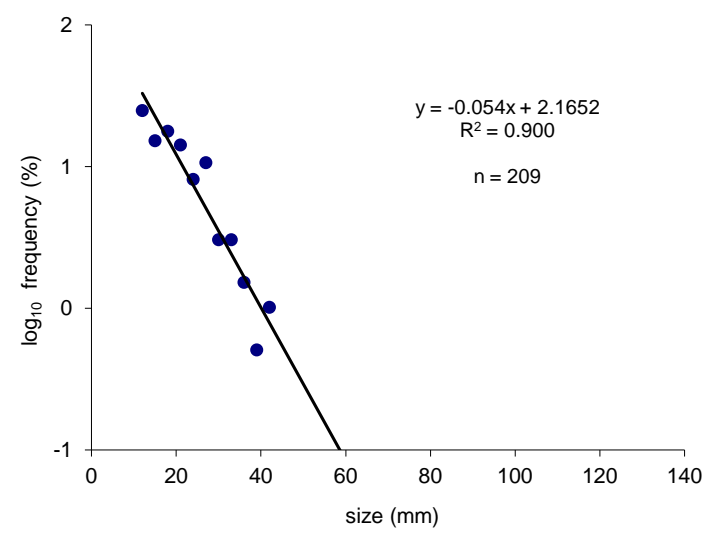


S7

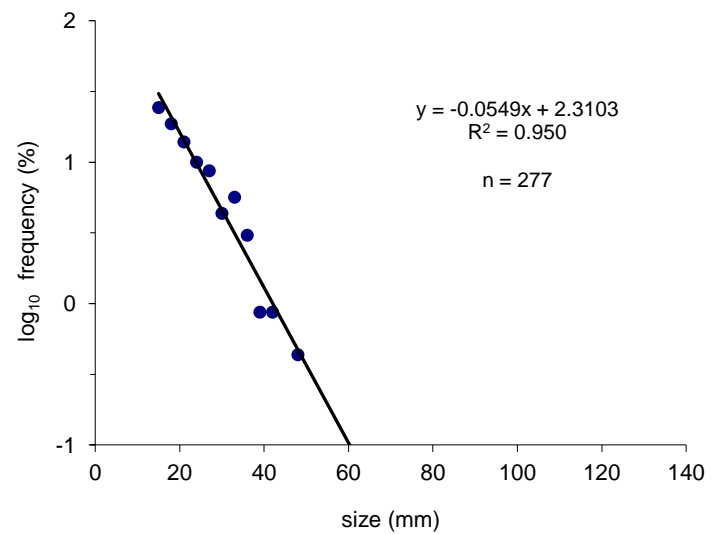

S9c

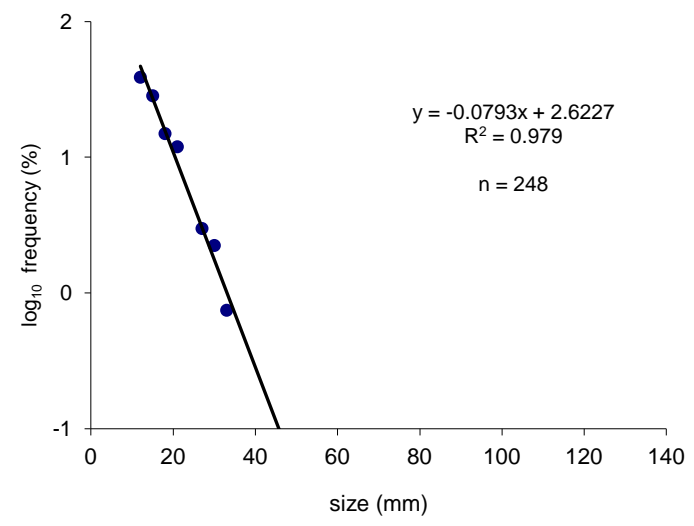

S8

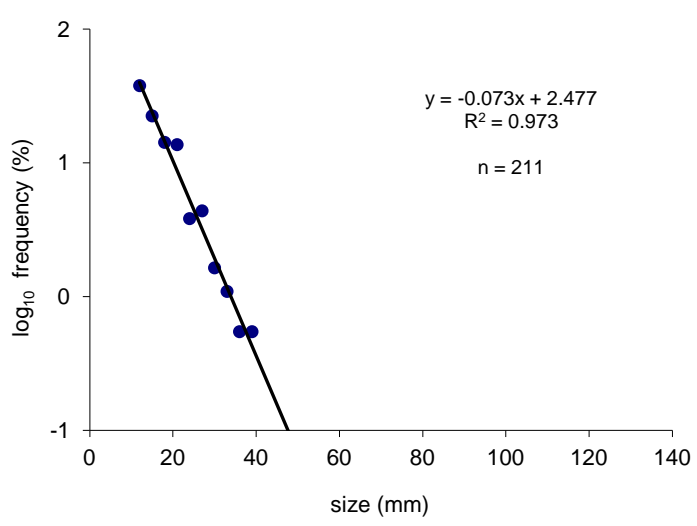

S9d

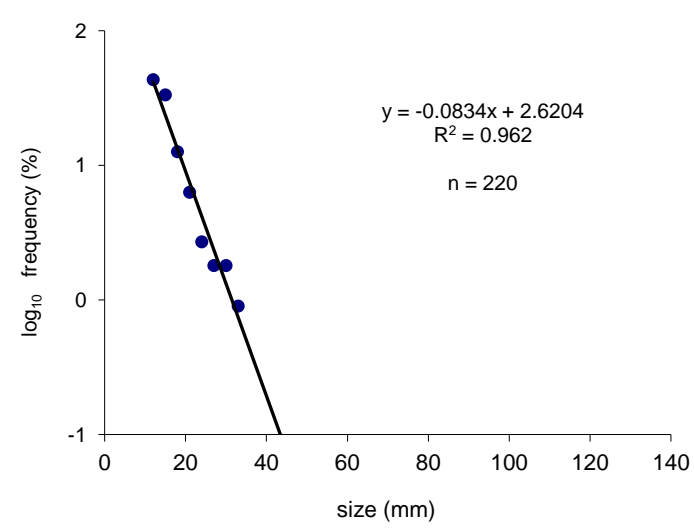


Skyndidalur

\section{Glacier}

retreat

\section{Vertical}

scale $(\mathrm{cm})$

0

50
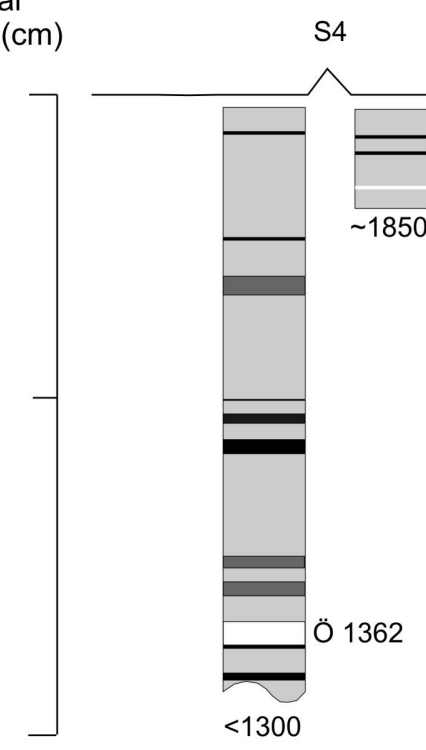

S5

S6

S7

S8 S9

S10

100

$<1300$

\section{KEY}

Black, basaltic tephra

Aeolian

soil

Grey tephra

White, silicic tephra

Hoffellsdalur

Vertical

scale $(\mathrm{cm})$

$\mathrm{H} 4 \quad \mathrm{H} 5$

$\mathrm{H} 6 \quad \mathrm{H} 8$

$\mathrm{H} 9$

0

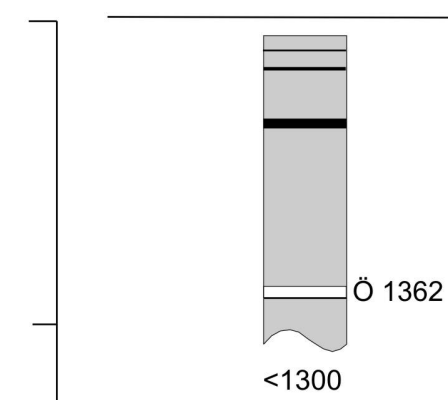




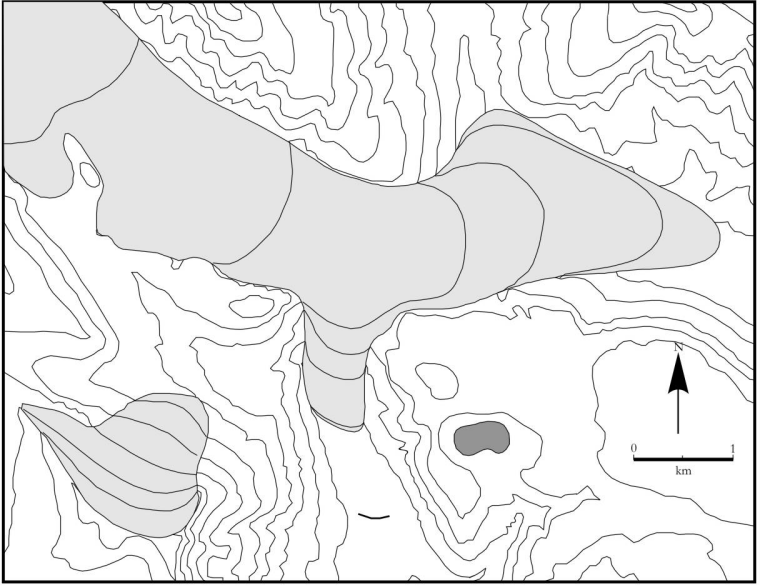

AD 1780s

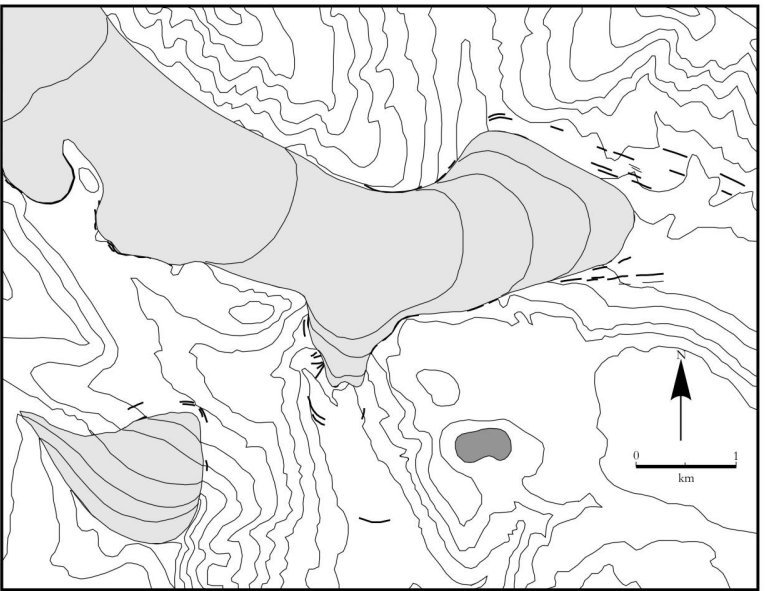

AD 1850s

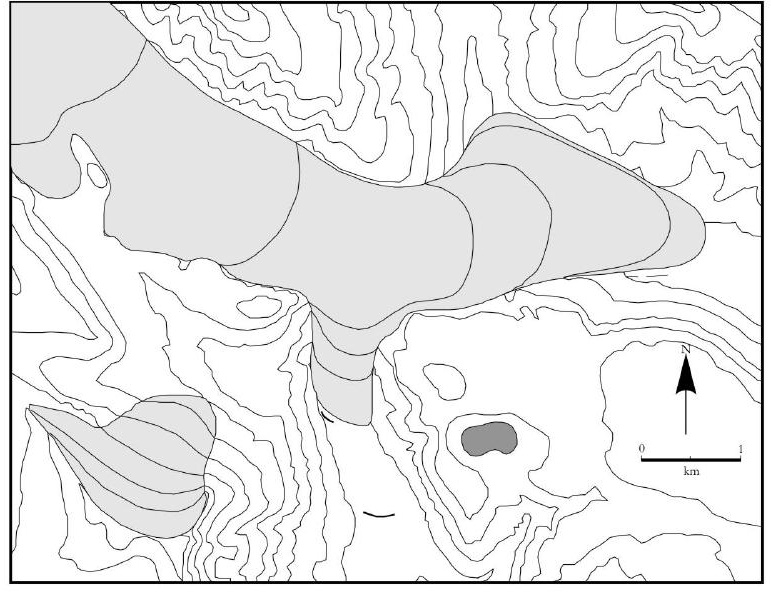

AD 1810s

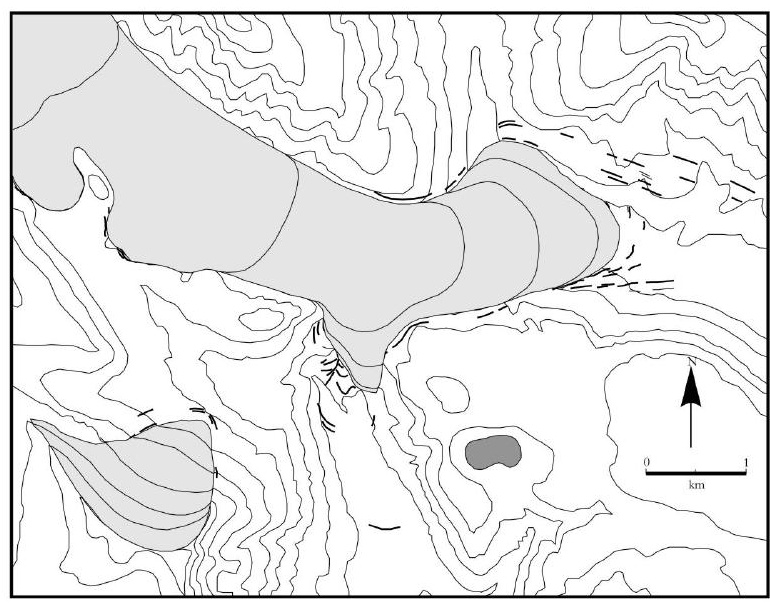

c. AD 1890

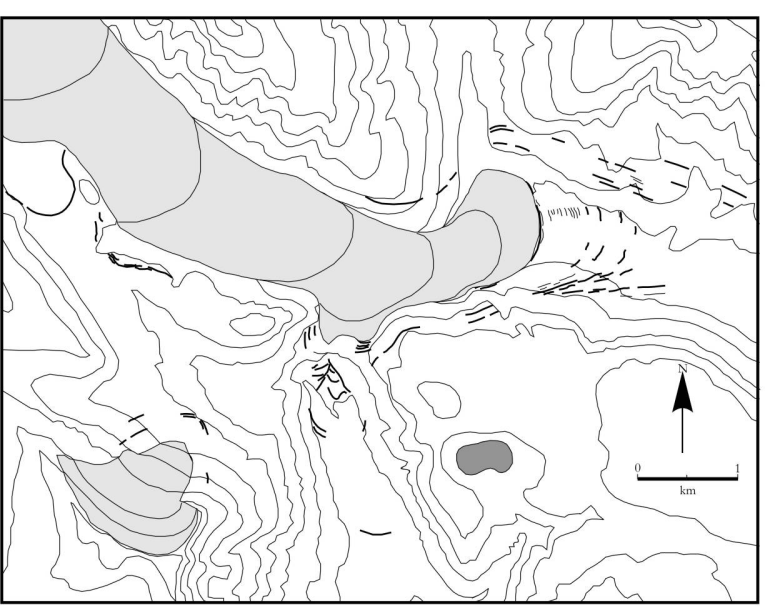

C. AD 1930

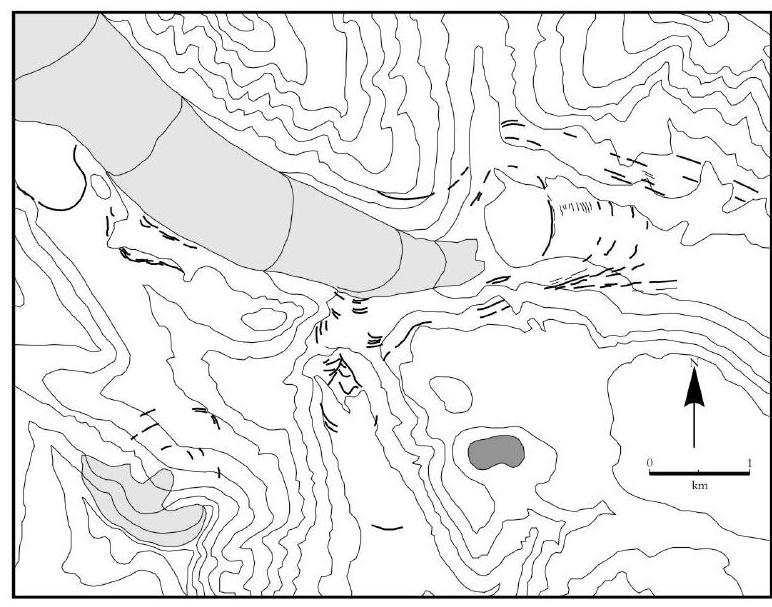

AD 1965 


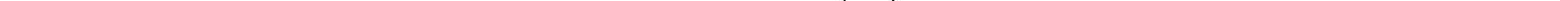




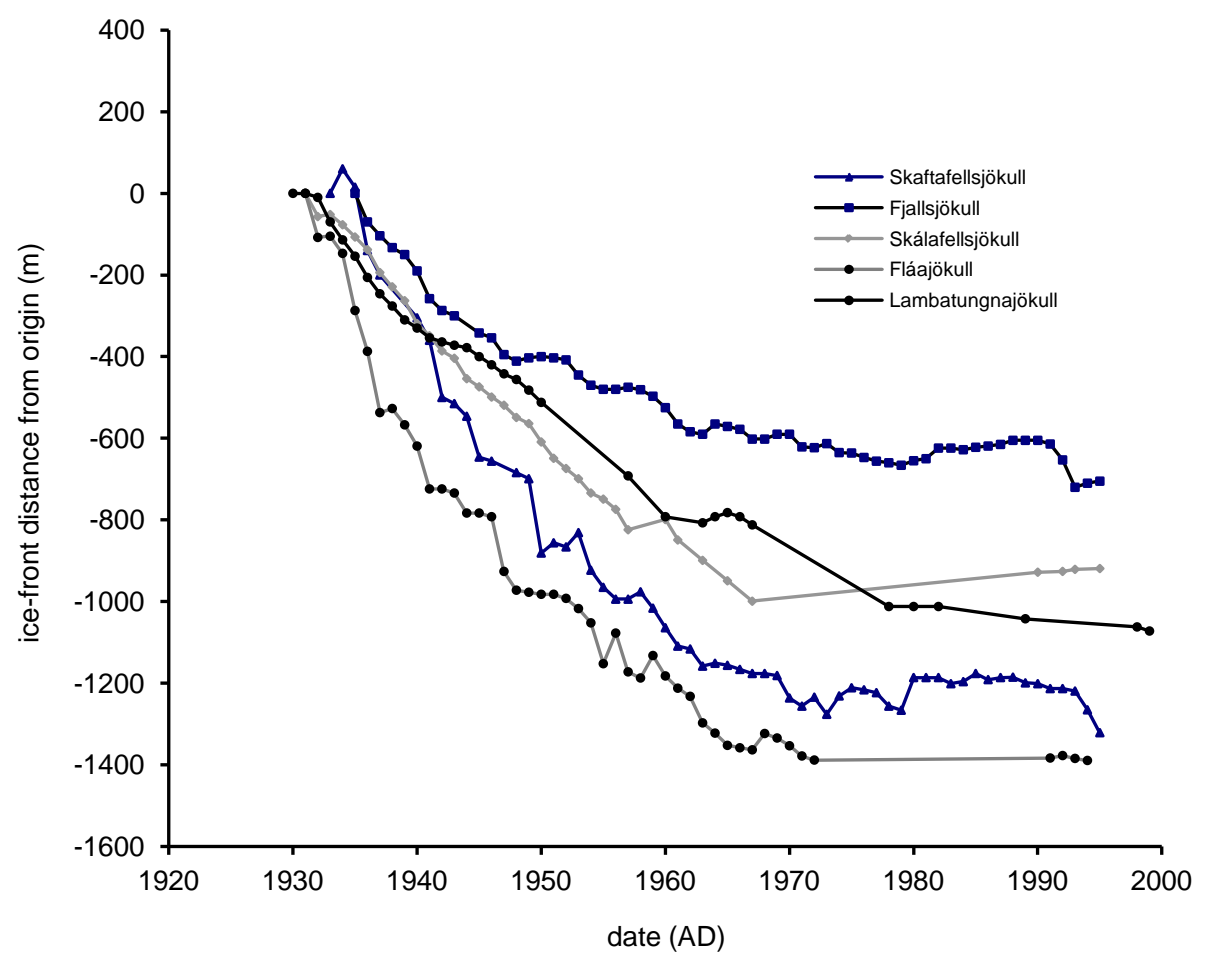


